\title{
SUSTAINABLE CITIES VERSUS POLITICAL CONTEXT: WHERE DO WE GO? THE CASE OF RADIO BASE STATIONS (RBS) OF PORTO ALEGRE/RS
}

\author{
CIDADES SUSTENTÁVEIS VERSUS \\ CONTEXTO POLITTICO: PARA ONDE RUMAMOS? \\ O CASO DAS ESTAÇÕES DE RÁDIO BASE \\ (ERB'S) DE PORTO ALEGRE/RS
}

Submission: $21 / 05 / 2019$

Accept: 18/12/2019

Cristiano Sordi Schiavi ${ }^{1}$

Eugenio Avila Pedrozo ${ }^{2}$

\begin{abstract}
This article aims to analyze the participation of social actors in the decision-making and political processes of the city of Porto Alegre, concerning the installation of Radio Base Stations (RBSs). Thus, an exploratory and descriptive research of qualitative nature was performed choosing the case of Porto Alegre. As a result, there was an environmental retreat in community participation and a change of orientation in the discussion about the possible adverse effects caused by electromagnetic of RBS. In a period of little more than a decade, the initial protagonism of the community was reduced, when a new discussion about changes in the Law emerged in 2013 and 2014. Finally, the article reinforces the importance of the political decentralization for Sustainable Development of cities, favoring the participation of local actors in the construction of environmental public policies.
\end{abstract}

Keywords: Public Policy; Sustainable Development; Urban Environmental Management; Cities; Radio Base Stations.

1 Graduation in Environmental Engineering by the Federal University of Rio Grande do Sul; Master in Administration by the Federal University of Rio Grande do Sul. PhD Student in Administration /Federal University of Rio Grande do Sul. Porto Alegre, Rio Grande do Sul, Brazil. E-mail: cristianosordi@hotmail.com ORCID: https://orcid.org/0000-0002-1072-2766

2 Doctor of INPL (Institut National Polytechnique de Lorraine, Nancy, France), professor in postgraduate management at UFRGS and UNIR (Federal University of Rondonia), main themes of interest: sustainability, systems and complexity, inter/transdisciplinary approaches, change and transformation, amazon social-ecological systems. Associate ("Titular") Professor at PPGA/EA/UFRGS (Federal University of Rio Grande do Sul). Porto Alegre, Rio Grande do Sul, Brazil. E-mail: 00010312@ufrgs.br ORCID: https://orcid.org/0000-0002-4751-707X 


\section{RESUMO}

Este artigo tem como objetivo analisar a participação dos atores sociais nos processos decisórios e políticos da cidade de Porto Alegre, concernentes à instalação de Estações de Rádio Base (ERB's). Assim, realizou-se uma pesquisa exploratória e descritiva de natureza qualitativa, escolhendo-se o caso de Porto Alegre. Como resultado, verificou-se um retrocesso ambiental na participação da comunidade e uma mudança de orientação no debate sobre os possíveis efeitos negativos causados pelo eletromagnetismo das ERB's. Num período de pouco mais de uma década, o protagonismo inicial da comunidade foi reduzido, quando emergiu nova discussão sobre mudanças na Lei em 2013 e 2014. Por fim, o artigo reforça a importância da descentralização política para o Desenvolvimento Sustentável das cidades, favorecendo a participação dos atores locais na construção de políticas públicas ambientais.

Palavras-chave: Políticas Públicas; Desenvolvimento Sustentável; Gestão Ambiental Urbana; Cidades; Estações de Rádio Base.

\section{INTRODUCTION}

A current global threat that can affect the public health in the urban environment is the result of the scientific technology widely employed by Telecommunications Companies in the last decades: the pollution caused by non-ionizing electromagnetic radiation, specifically in the present research, the radiofrequencies transmitted by Radio Base Stations (RBSs).

Epidemiological studies show evidence that populations around RBSs presents a higher probability to develop cancer than non-exposed populations (Dode, 2010; Eger et al., 2004; Wolf, R., \& Wolf, D. 2004). In turn, the World Health Organization and the International Agency for Research on Cancer classified in 2011 the radiofrequency electromagnetic field as "possibly carcinogenic" to humans, based on an increased risk for glioma, a malignant type of brain cancer, associated with wireless phone use (larc, 2011). An extensive international scientific report has concluded that the present limits of public health protection are not adequate and new limits are necessary in accord with the precautionary principle. (Bioinitiative Report, 2012). In a way, this situation is similar to what happened in the case studied, because the focus of the present research occurred in a discussion about a legal repositioning in relation to RBSs, in the Municipality of Porto Alegre, capital of the State of Rio Grande do Sul (RS), Brazil.

It also highlights the significant expansion of the Mobile Communications Sector in the Brazilian market in recent years. The country ended October 2015 with 273.79 million active lines in mobile telephony (Anatel, 2015a), compared to 25.4 million on May 2001 (Anatel, 2001). To meet this demand of users, mobile operators must invest in telecommunications infrastructure, which includes the installation of RBSs in Brazilian cities. In December 2015, approximately 75 thousand RBSs were registered in the country. The RS has a significant network of RBSs, occupying the fourth position (5032), behind only the states of Minas Gerais (8312), Rio de Janeiro (8505) and São Paulo (19253). In the Municipality of Porto Alegre, 985 RBS's were verified - about $20 \%$ of RS's ERBs (Anatel, 2015b).

In parallel, the environmental issue is often approached in the present through the concept of Sustainable Development. In the situation of radiofrequency exposure emitted by RBSs in the urban environment, local authorities can create public policies for this issue, controlling the possible impacts to human health, in accordance with the assumptions of Sustainable Development of cities. This is the case of RBS's public policies in Porto Alegre, which adopted, in an initial decision on the subject, more restrictive limits of exposure to non-ionizing radiation in places considered "sensitive" in the city (those where people remain for most of the time, such as apartment buildings, nurseries, schools, hospital rooms, geriatric institutions, workplaces, among oth- 
ers), which are ten times lower than the standards established by the national telecommunications agency in the country - Resolution 303 / 2002 of "Agência Nacional de Telecomunincações" (ANATEL) - and Federal Law no. 11.934 / 2009, both based on the safety limits of the International Commission on Non-Ionizing Radiation Protection (ICNIRP).

The theme of this research is inserted in the context of uncertainties of technoscience in contemporary society and unpredictability of its consequences for public health and Sustainable Development of cities. In this context, Beck (2011) emphasizes in modernity an overlapping of the problems and distributive conflicts of society with the problems and conflicts originating in the production, definition and distribution of scientifically-technologically produced risks. Although technological advances in mobile telephony are providing benefits for communication between individuals, new threats to the environment and public health can arise from this technology. In this context, the Municipal Public Power can assume its legislative and administrative responsibilities for protecting and improving the environment, disciplining the installation of RBSs in the urban territory, in a social negotiation, among actors with conflicting logics, such as technological innovation and the economic power of companies versus environmental, health and urban planning. This is what the Municipal Law 8896/2002 seeks, case study chosen in this research, which regulates the environmental licensing of RBSs, according to health norms and the precautionary principle, in Porto Alegre.

In Brazil, the case of Porto Alegre can be considered special, because the municipality was a pioneer in the elaboration of protectionist legislation in the local scope for the subject of the RBS's. In this political issue, the community movement played an essential role in claiming to the Municipal Public Power a legislation for this issue, mobilizing the neighborhood associations of Porto Alegre and various social actors at the beginning of the millennium, such as representatives of Universities, of Public Ministry, of the Executive and Legislative Powers. However, the Executive Law Project $n^{\circ}$ 57/2013 was created with the purpose of updating Municipal Law $n^{\circ}$ 8896/2002, raising concerns in the community about possible health impacts. At that moment, the companies were protagonists in proposing changes in the legislation of RBS's of Capital.

In the face of the local pluralistic political scenario, the Porto Alegre pioneerism in the elaboration of a specific Law for ERBs in Brazil, considered a reference for other municipalities in the Country, of the recent change of the Municipal Law, and of the importance of this theme for the Sustainable Development of cities, this research has as an objective to revisit the debate of this municipal public policy, analyzing the participation of social actors in the decision-making and political processes, concerning the installation of RBS's in Porto Alegre.

The text is structured in five sections. This introduction (1) followed by the literature review of Sustainable Development (2). The third and fourth sections detail the method (3) and the results and discussions of the research (4). In the last section, the conclusion (5) are presented.

\section{LITERTURE REVIEW}

In the literature review, public policies and international conferences are presented, as well as aspects related to Sustainable Development and cities are discussed.

\subsection{Sustainable Development and International Public Policies}

In the building of the consciousness of Sustainable Development, numerous international conferences were fundamental in creating official policies for environmental protection. 
Contained in the notorious report Our Future Common, also known as Brundlandt, it's important to remember the classic definition of Sustainable Development as one that meets the needs of the present generations without compromising the ability of future generations to meet their own needs (United Nations, 1987).

Products of United Nations Conference on the Human Environment (1972) and the United Nations Conference on Environment and Development (1992), the Stockholm (1972) and Rio (1992) Declarations emphasize the responsibility of National States to protect and improve the environment, with strong repercussions on the principles of Environmental and International Law. Agenda 21, also a result of the United Nations Conference on Environment and Development (1992), establishes a commitment of the National States to the Sustainable Development of the planet, recognizing the role of cities and local authorities in this process (Brasil, 1995). Following the United Nations Conference on Environment and Development (Rio 92), there were the World Summit on Sustainable Development (Rio+10), held in Johannesburg in 2002 (South Africa), and the United Nations Conference on Sustainable Development (Rio+20), with headquarters once again in Rio de Janeiro in 2012.

In Rio+10, Diniz (2002) emphasizes the highlight given to the problems of globalization, as well as the details of an implementation plan that initiates a collective action toward environmental protection in association with economic and social development, although not indicating quantitative targets. Guimarães and Fontoura (2012) criticize the lack of progress made in the international environmental debate during Rio+10. In a similar way to the results obtained in Rio+10, the authors cited consider Rio+20 little significant, suffering from the same insufficiencies in relation to the failed Rio+10, or even not retreating even further in the commitments assumed twenty years ago. Also according to the authors cited, representative groups of society, about a thousand organizations, were concerned about the directions of Rio+20, who endorsed the document Deleting our Rights, Bracketing our Future, of the Peoples' Summit. In this document, there are warnings and apprehensions about human rights and the struggle for more equality, as well as principles already agreed upon - 'Polluter-Payer', 'Common but Differentiated Responsibilities', 'Principle of Precaution', among others (Guimarães \& Fontoura, 2012).

In September 2000, a global consensus on the importance of poverty reduction and human development culminated in the adoption of the Millennium Declaration by 191 nations. Its purpose is to achieve the eight Millennium Development Goals by 2015: (1) universalize primary education, (2) promote gender equality and autonomy of the woman, (3) reduce child mortality, (4) improve maternal health, (5) combating HIV / AIDS, (6) malaria and other diseases, (7) ensuring environmental sustainability, and (8) establishing a global partnership for development (United Nations, 2012).

However, in the United Nations study entitled World Economic and Social Survey 2013, the international body recognizes failures in the actual implementation process of Sustainable Development, emphasized by Agenda 21 as the interconnection between its three dimensions (promoting economic and social well-being while protecting the environment). The publication also reports that currently about one billion people live in places without infrastructure and access to basic services, projecting an increase of three times by 2050 if the current political framework is not reversed. Moreover, it reveals that, since 2007, more than half of the world population lives in urban centers, estimating that the proportion reaches $70 \%$ in 2050 (United Nations, 2013).

The only real result of Rio+20 was the proposal to create the Sustainable Development Objectives to expand the Millennium Development Goals by means of indicators to help govern- 
ments implement the commitments set out in Agenda 21, the Johannesburg Plan and Rio+20. (Guimarães \& Fontoura, 2012). In September 2015, the United Nations unanimously approved the document "Transforming Our World: The 2030 Agenda for Sustainable Development" - with its 17 new global objectives and 169 goals. In the current agenda, with post 2015 goals, there is a clear conviction about the urgent need to take bold and transformative steps to put the world on a sustainable and resilient path. (United Nations, 2015).

To exemplify the ambitions of this Agenda, Objective 1 aims to eradicate extreme poverty by 2030 and to reduce by at least half the proportion of men, women and children, of all ages, living in poverty, in all their dimensions. It's the first objective of the plan, to be complied between 2015 and 2030. That is, in just 15 years. In Objective 11, the issue of cities is addressed, which must become inclusive, secure, resilient and sustainable. In Objective 16, the theme of social participation in public policies is highlighted, which seeks to promote peaceful and inclusive societies for sustainable development, provide access to justice for all and build effective, responsible and inclusive institutions at all levels. From this scenario, the theme of Sustainable Development has been gaining increasingly importance in the construction of public policies that face the diverse complex problems existing in the cities.

\subsection{Sustainable Development and Cities}

Satterthwaite (2004) highlights an increased official recognition in the discussion of Sustainable Development and cities in the 1990s. According Satterthwaite (2004), the expressions "sustainable cities" and "sustainable human settlements", for example, were widely used in Habitat II, the second United Nations Conference on Human Settlements - took place in Istanbul in 1996.

Corroborating this view, Allen (2009) emphasizes that the notion of cities playing a key role in Sustainable Development has become a popular idea and taken into account in planning and policy making only in the early 1990s. This worldwide concern with Sustainable Development and cities is present in publications from international organizations. In 2013, for example, the work entitled Planning, Connecting, and Financing Cities - Now: Priorities for City Leaders, of the World Bank, indicates the creation of policies and investments as a strategic strategy for sustainable and resilient development in a future scenario of rapid urbanization in the cities of emerging economies (World Bank, 2013). Recently, in 2016, Habitat III - United Nations Conference on Housing and Sustainable Urban Development - took place in Quito, Ecuador, with the creation of a New Urban Agenda, which is committed to working towards an urban paradigm shift, emphasizing the promotion of participatory approaches in this process of change.

In Brazil, Federal Law 6.938/1981 establishes the National Environmental Policy (Brasil, 1981), which is considered by Milaré (2013), the great institutional framework of environmental management in Brazil. The Law 6.938 / 1981 also constitutes the National System of the Environment, involving the organs and entities of the Union, States, Federal District, Territories and Municipalities, as well as the foundations instituted by the Public Power. In 1988, the Democratic State of Law was established, after a long dictatorial period in Brazil, with the promulgation of the Constitution of the Federative Republic of Brazil (Brasil, 1988), assigned to the Public Power a set of legislative and administrative functions for the protection and improvement of environmental quality.

In this complex system of Brazilian environmental protection, the municipalities are fundamental pieces in the management and formulation of public environmental policies, having the constitutional administrative and legislative competency in this matter. As observed by Menegat and Almeida (2004), Municipalities are essential vectors in the Brazilian Public Administra- 
tion, expanding, in the last decades, its area of action in matters covered only by the Union or the States (education, health, environmental management, safety). These new municipal responsibilities are resulted from the Federal Constitution of 1988 and the important social and popular movements that led the country to democratization (Menegat \& Almeida, 2004).

In order to discipline urbanization in the country, a fundamental regulatory framework was Federal Law no 10.257/2001 (Brasil, 2001). The art. 2, item I, of Law no 10.257/2001, establishes as guideline for urban policy the guarantee of the right to sustainable cities, understood as the right to urban land, housing, environmental sanitation, urban infrastructure, transport and public services, work and leisure, for present and future generations.

Established by Law no 10.257/2001, the Master Plan can be considered a fundamental instrument for Sustainable Development in urban centers. According to Antunes (2013), the most important legal advice for business life is the Master Plan, which is the basis of the guidelines and standards for proper urban land occupation. One of the general guidelines of Law no $10.257 / 2001$ is democratic management, which guarantees the participation of the population and representative associations of the various segments of the community in the formulation, execution and monitoring plans, programs and projects of urban development (Brasil, 2001).

Thus, the Brazilian Law already institutionalized the right to sustainable cities and created instruments of social participation, such as the Master Plan, which provides for participatory and democratic management. In this sense, it's evident in the construction of national policies related to the environment the institutionalization of sustainable development, in accordance with the purposes of international policy documents, taking as an example the Agenda 21.

For Menegat and Almeida (2004), the two guidelines in the development of environmental management programs in recent years are Sustainable Development and citizen participation, both defined in the document Agenda 21. Despite their international character, the initiatives of the local authorities in support of Agenda 21 are decisive in the realization of their objectives. In this regard, Chapter 28 of Agenda 21 emphasizes the preponderant role of local authorities in favor of Sustainable Development, contributing to the implementation of national and subnational environmental policies (Brasil, 1995). Milaré (2013) emphasizes the meaning of Agenda 21, conditioned to the implementation of national agendas, and these, in turn, suppose the elaboration of local agendas. For Milaré (2013), this is one of the ways, perhaps the best, to put into practice the already well-publicized refrain: Think globally, act locally. In other words, from the Global Agenda for the Local Agenda.

At the seminar Innovations in Local Agenda 21 in Urban Areas of Latin America, held in 1999 in Porto Alegre, the conclusions of this event pointed to great difficulties in the implementation of Agenda 21 in most Brazilian and Latin American municipalities, although it's in the local area where the best experiences were verified (Menegat \& Almeida, 2004). According Menegat and Almeida (2004), in solving the conflicts of the urban-social-environmental apartheid, or in the management of the various interests of urban groups, public management, in most municipalities, practicing excessive centralism in their action planning, ruled as purely technical attribute, forgetting the role of citizens in decision-making and implementation of programs that draw the future of cities.

In this context, Satterthwaite (2004) proposes multiple Sustainable Development goals applied to cities, considering social, economic and political goals, based on the Brundtland Declaration. The model proposed by Satterthwaite (2004) emphasizes the relevance of the political dimension as an institutional regulatory framework, in which local authorities ensure the achievement of Sustainable Development goals in cities. In the same direction, Allen (2009) outlines a 
model of Urban Sustainability based on five dimensions: Economic Sustainability, Social Sustainability, Ecological Sustainability, Physical Sustainability and Political Sustainability. Of particular note is the political dimension in this proposal, which guides the relationships and actions of the different social actors among the other four dimensions, implying democratization and local civil participation in all areas of decision-making (Allen, 2009).

Sachs (2004) also underlines the importance of the political dimension as one of the central demands of Sustainable Development, based on five pillars: Social, Environmental, Territorial, Economic and Political. For Sachs (2004), the political pillar of Sustainable Development is based on democratic governance - a value considered foundational and necessary, as well as freedom.

Menegat and Almeida (2004) proposes the adoption of public policies to integrate environmental management to help visualize the specificities of each municipality along the way in pursuit of Sustainable Development objectives, presenting four important spheres in the process of integration and construction of Urban Environmental Management: (1) knowledge, (2) urban-social-environmental-public management, (3) education and information, and (4) citizen participation.

Menegat and Almeida (2004) consider as essential presupposition the existence of a network, so that each sphere establishes necessary relations with all the others, which leads to the reorganization of the functions of each of them. It emphasizes the sphere of citizen participation in which the community must be called upon to build the management of the urban-social-environmental system, based on a deeply democratic, humanistic and culturally tolerant system of government. For Menegat and Almeida (2004), this participation, one of the most important points of Agenda 21 and also of the Habitat Agenda, has the property of changing the conceptual premises of other spheres at the same time, because the local issues become relevant, and promote a new culture of city management, when society begins to formulate and control the public policies of daily life. Thus, we can observe a multidimensional approach of Sustainable Development, which considers the environmental issue from the point of view of the relationship between society and nature, including the political participation of citizens in cities as a central question.

\section{METHOD}

This research aims to revisit the debate on municipal public policy, analyzing the participation of social actors in the decision-making and political processes of the city of Porto Alegre / RS / Brazil, concerning the installation of RBS's. Thus, an exploratory and descriptive research with a qualitative approach was chosen, and for this, a case study was carried out. According to Flick (2009), the pluralization of the spheres of life requires a new sensitivity for the empirical study of the questions and, in this direction, qualitative research is of particular relevance to the study of social relations.

Thus, the unit of analysis of the present research is the Municipality of Porto Alegre, analyzing the process of implementation of the public policy of RBS's - Municipal Law no. 8.896/2002 and the political participation of citizens. The case of Porto Alegre was chosen by non-probalistic sampling, considering its relevance, because in Brazil, the municipality was a pioneer in the elaboration of protectionist legislation for the issue of RBSs, becoming a reference for other Brazilian municipalities. For Yin (2015), the case study as a research effort contributes singularly to the understanding of individual, organizational, social, and political phenomena. After the definition of the unit of analysis of the case study, we started to collect data. Yin (2015) states that there are several ways to collect data in a case study, and can combine more than one type of collection in 
the same study, which contributes to the breadth and validity of the research construct. Therefore, in this research, observations and interviews were made to obtain primary data, as well as secondary data collected from documentary sources.

The data collection began in 2014, identifying the various social actors in the process of implementing RBS's public policies in Porto Alegre. At this stage of the research, the observation and data collection was used in the public hearing about Executive Law Project $n^{\circ} 57 / 2013$, on June 26, 2014, in order to get items to problematizations research,. Thus, the observation protocol included observations related to the legislative competence of municipalities in relation to environmental, urban and public health issues, in the case of the implementation of public policies of RBSs; the participation of society in the making of municipal decisions; and divergences among social actors about the environmental consequences of Executive Law Project $n$ o 57/2013 for the population.

In order to describe the process of implementation of RBS's public policies in Porto Alegre, a semi-structured interview with the social actors involved in the discussion of Municipal Law no 8.896/2002, which took place in 2016. For this, an interview script was elaborated, contemplating the four important spheres in the process of integration and construction of Urban Environmental Management: (1) knowledge, (2) urban-social-environmental-public management, (3) education and information and 4) citizen participation (Menegat \& Almeida, 2004). As the interviews happened with the main social actors identified in the Public Hearing, new social actors were indicated by the interviewees as possible sources of data for the research. This is the snowball technique, in which the respondents are located with the use of reference network (Cooper \& Schindler, 2011). In total, 16 interviews were conducted to analyze the data of this research.

In addition, legislative-documentary sources were explored, related to Municipal Law № 8.896/2002 and Executive Law Project no 57/2013, collected in 2016. Legislation of ERBs was also investigated at the state and federal levels, as well as judicial decisions. In addition, local newspapers documents were consulted in Zero Hora (private access) and Correio do Povo (public access) media collections, as well as on-line and printed documents donated by social actors. This method of research was important to verify the positioning of cellular companies in the Judiciary and in the Media, as well as their view on Municipal Law $n=8.896 / 02$, because it was not possible to conduct interviews with cell phone companies and with the Union that represents mobile service in the Country.

After collecting this material, broke for the processing and analysis of data. The analysis and interpretation of the data was performed according to the theoretical elements proposed by Menegat and Almeida (2004) for Urban Environmental Management of cities, emphasizing in this model the sphere of citizen participation, through the technique of content analysis. For this, all interviews were transcribed, as well as treated the observations and documents, in order to allow a better operationalization of the data for analysis. According to Schreier (2013), content analysis seeks to describe the meaning of qualitative data by assigning categories to the material collected in a coding frame that presents all aspects of description and interpretation. Thus, for this research, the codes of analysis were derived from the main sphere analyzed in the context of the research: citizen participation. From the analysis of this sphere, were distinguished two political moments of relevance in public policies of RBS's in Porto Alegre.

\section{RESULTS AND DISCUSSION}

In the first political moment, the genesis of Municipal Law $n=8.896 / 2002$ was marked by the involvement of several social actors, who discussed intensely in the City Council of Porto 
Alegre the concerns raised by the population regarding the possible health damages caused by the installation of RBS's in the city. In this debate, the community played an important role in the political mobilization of the neighborhoods of Porto Alegre. This is reported by the Councilor of environmental movement - "Associação Gaúcha de Proteção ao Meio Ambiente" (AGAPAN), E5, who acted strongly in this community movement of the municipality:

All this process, which we lived in Porto Alegre, had a beginning with the neighborhood communities. (...)There were many people (...) connected to the neighborhoods who were worried about this situation. We got more than 1000 signatures at the time (...) and filed with the Public Ministry. The Public Ministry has seen the legal issue, (...), suspended there the installation of the tower and also (...) 8 installation of towers at the time (...). We, at that moment, made a community movement, but a community movement alone, perhaps, had not been able to provoke the City Council to change its position of favoring companies. (E5, 2016)

It has verified, in this assertion, the importance of the Public Ministry in the investigation of environmental problems in the city, raised by the population, as well as the need for conjunction of social actors for the political confrontation in the City Council of Porto Alegre. On this scenario of great political confrontations in the City Council, the former Councilor (1996-2004), E10, author of Law $n$ o 8.896/2002, emphasizes the importance of the collective effort of several social actors in the discussion of the legislation of Porto Alegre:

Only with the scenario that at that moment was established that it is possible to approve a Law like this (...) and only with the participation of the community, legitimation by the Public Ministry (...).Today these companies are the strongest companies in the economy. (...) However, there is a principle, precautionary principle, which in the environmental area must prevail. In scientific doubt, when you have researchers who say a certain product or service is bad for your health, when it's divided, (...) the precautionary principle must always prevail in the environmental issue and (...) based on many studies, we have been able to reduce the power density level of our towers. (...) If it does not have this participation of the University, the Public Ministry and the community, the companies would have prevalence in their interests at that moment, at least in the City Council. However, as it was very strong the participation of the community, of the Public Ministry, it ended up that the interests of society prevailed. (...) Never, at that moment, did we want to bring losses to communication or business. We wanted to ensure the safety of people's health and it was a phenomenon of citizenship. (E10, 2016)

The precautionary principle, which deals with the uncertainty of scientific knowledge and its risks, should be emphasized, ensuring stricter standards of radiofrequency emissions, such as those defined by Switzerland and followed by Municipal Law $n=8.896 / 2002$, without any detriment to the provision of a quality service by the Telecommunications Sector in the Municipality. The invocation of this principle is essential in the current social context, since, in modern society, the emergence of scientific-technological risks, as pointed out by Beck (2011), is increasingly frequent. For Antunes (2013), this principle does not cause the stoppage of activity, but the adoption of the necessary care, even for that scientific knowledge can advance and clarify the doubts. Thus, the precautionary principle in Principle 15 of the Rio Declaration must be applied by States. The result of all this participation of the society in the construction of public policies of RBS's was the successful approval of Municipal Law $n=8.896 / 2002$, by a large majority of votes.

After the Municipal Law $n=8.896 / 2002$ came into force, the companies had to adapt immediately to the power density levels, and within a maximum period of 36 months regarding the other criteria. Expiring the deadline determined by law, according to Zero Hora report, the 
Municipality of Porto Alegre identified 154 towers outside the criteria of the legislation. The Municipal Public Power proposed a Conduct Adjustment Declaration with the operators, which would reduce to 30 non-standard towers, flexibilizing some points of the Law (reduction to three meters of the minimum distance between towers and buildings and limit of 450 meters between two or more towers), in exchange for environmental compensations (Zero Hora, 2005a). However, there was no agreement between Municipality of Porto Alegre and the representatives of the operators. In the report of Zero Hora, the counterpoint of the companies is argued by a representative of the National Association of Mobile Operators - "Associação Nacional de Operadoras Celulares" (ACEL):

Unfortunately, it was not possible to sign an adjustment agreement with Municipality. (...) We will take all appropriate measures against this decision. Thus, we will gain a deadline to discuss the reality and legality of this municipal law, which in our opinion is unconstitutional. (Zero Hora, 2005a)

Clearly, the position of the companies is contrary to Municipal Law no 8.896/2002, considered unconstitutional by ACEL, assuming as a strategy the judicialization of this political issue in Porto Alegre. This is a worrying phenomenon in Brazil because transfers the decisions of the Executive and Legislative Powers to the courts and magistrates, who do not have knowledge of all aspects of the policy-making process.

The Municipal Environmental Secretariat - "Secretaria Municipal do Meio Ambiente" (SMAM), and the Municipal Attorney General's Office, then, said that they would conduct the process of assessment of the companies, applying a fine for non-compliance with the Law (Zero Hora, 2005a). In fact, according to another report from Zero Hora, two companies received 98 infraction notices, with an estimate that the amount will reach around $\mathrm{R} \$ 20.000$ per non-standard antenna, and $\mathrm{R} \$ 2.000$ per day. At that time, the ACEL published a statement in newspapers warning that more than 1 million users could be prejudiced (Zero Hora, 2005b). As a counterpoint to this report, the Municipal Secretary of Environment, at the time, strongly criticized the operators:

This is terrorism from mobile operators. Society cannot admit it, because it's blackmail. The companies had three years to adapt, and were never against. The law is not a top-down decree; it was discussed with the population and with the operators, and was unanimously approved by the City Council. It's based on Swiss law, and there the telephony works very well. (...)We were pioneers in the country, after Curitiba and Campinas made similar laws and ANATEL created a group to discuss the matter with reference to Porto Alegre. ANATEL knows the situation and has assured that the signal will be maintained. (Zero Hora, 2005b)

On another occasion in the Journal Zero Hora, the Secretary of the Environment, at the time, categorically stated the possibility of harmonizing the economic interests of the Telecommunications Sector with the social and environmental issues raised by the population, which were reflected in the provisions of the Law Municipal no 8,896 / 2002. Moreover, it revealed the fallacy of the companies in the attempt to disqualify the public policy of RBS's in the Municipality of Porto Alegre (Zero Hora, 2006). In reality, the operators simply disobeyed the Municipal Public Power, taking as a strategy the judicialization of this policy, ignoring a democratic process of creating the Law at the local level.

The second political moment began with a proposal to update Law 8896/2002 by companies, represented by technicians of the Federation of Industries of the State of Rio Grande do Sul - "Federação das Indústrias do Estado do Rio Grande do Sul" (FIERGS) (FIERGS), in the City Council in 2011. These changes in the Law, according to the representatives of the operators, 
had as objective to make possible the technology of fourth generation, better known as " $4 \mathrm{G}$ ", in the Capital. (Porto Alegre, 2012). The result of this business initiative in the City Council was the Legislative Law Project no 160/2011, authored by the Councilor and President of the 2014 World Cup Commission, which proposed the repeal of Law $n=8.896 / 2002$ and the flexibilization of the rules that governing the installation of RBSs in Porto Alegre.

As verified in a report in the Journal Zero Hora, the Legislative Law Project $n=160 / 2011$ was considered very soft in relation to companies, being criticized by proponents of strict norms against electromagnetic emissions. According to the companies, the current legislation would be the main cause of areas without signal in Porto Alegre, imposing minimum distance 50 meters of hospitals, educational institutions, nurseries, clinics and health centers (Zero Hora, 2013). Certainly, some interviewees in the research cited dissatisfaction with this provision of the Law. However, there is no contrary reference by companies regarding the lower radiation limits, which were stipulated in the legislation of Porto Alegre.

Facing this situation, Executive Law Project no 57/2013 was proposed on December 16, 2013 in the City Council. It is at this scenario that the debate on the changes in Municipal Law no $8.896 / 2002$ began in 2014, with only a public hearing being held on June 26,2014 , thanks to a judicial decision filed by AGAPAN, which raises concerns about social participation in city decisions and access to relevant environmental and health information to the community. Figure 1 shows a manifestation contrary to the Executive Law Project $n$ 0 57/2013, observed during the public hearing, in which the poster is written as follows: "THE PEOPLE KNOWS COUNCILLORS, CHANGE THE LAW OF THE ANTENNAS ONLY BENEFITS THE COMPANIES".

Figure 1 - Public hearing in the City Council of Porto Alegre.

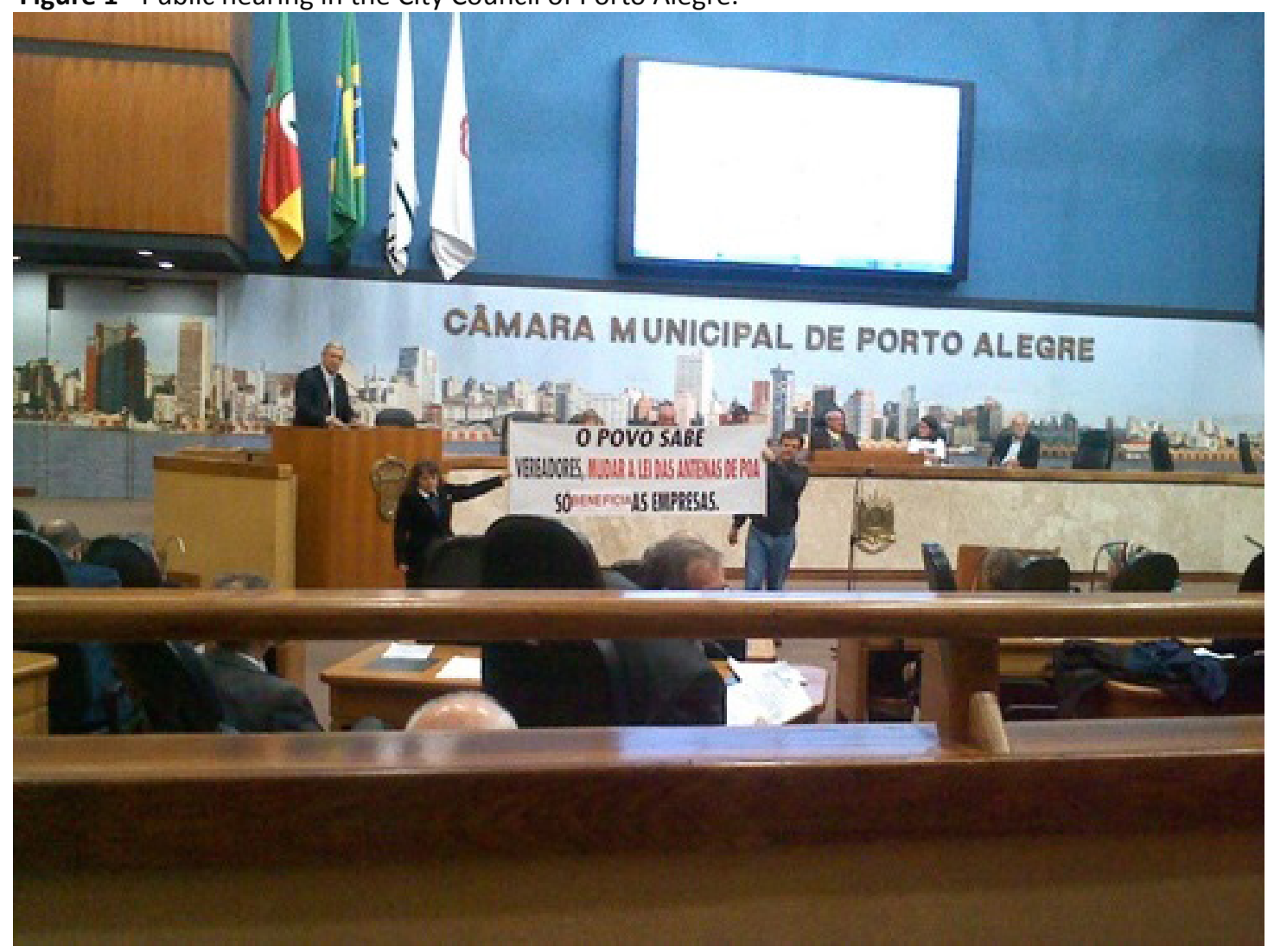

Source: Research data, 2014. 
The result of Executive Law Project no 57/2013 was its approval on July 16, 2014, by 21 votes to 4 , with the revocation of the main target of criticism by the companies: the exclusion zone of 50 meters of hospitals, educational institutions, nurseries, clinics and health centers. In fact, in the explanation of the Teachers of the Universities of the Federal University of Rio Grande do Sul - "Universidade Federal do Rio Grande do Sul" (UFRGS), E1, and of the Pontifical Catholic University of Rio de Janeiro, E13, the levels of electric field and power density are more relevant for the discussion of the Law, than the rule that provides for a 50-meter exclusion zone.

However, at the time of the second political moment under review, there was not a wide scientific discussion that took into account, for example, the recommendations indicated in the year 2012 in the letter of the State Seminar "The risks of non-ionizing electromagnetic radiation from cellular telephony", based on the principle of precaution, and the classification of International Agency for Research on Cancer in 2011about radiofrequency electromagnetic field as "possibly carcinogenic" to humans. Neither the express warning expressed in Resolution 1811/2011, in which the Parliamentary Assembly recommended to the Member States of the Council of Europe the application of the ALARA (As Low As Reasonably Achievable) principle, that is, to use limits as low as reasonably possible, since ICNIRP levels have serious limitations. By the way, the Bioinitiative Report (2002) recommends new limits required in accordance with the precautionary principle.

In this debate, it's important to emphasize the results of the research on the protective levels of radiofrequency exposure, adopted in Porto Alegre. Harmoniously, experts and technicians from the telecommunications area, from UFRGS (E1), from SMAM (E9), and from ANATEL (E7), interviewed in this research, have ensured that these levels of protection are fully met by cellular operators. However, changes in the legislation of Porto Alegre occurred in 2014 deviate from the desired protective ideal, since the protective limits were restricted to "critical" sites (hospitals, clinics, schools, nurseries and geriatric institutions, located 50 meters of the RBS), excluding residences and workplaces, without there being any progress towards new even more protective levels for all regions of the city.

On the occasion of the Public Hearing, the scientific knowledge produced at the Seminar was simply labeled ideological by Deputy Mayor Sebastião Melo and some Councilors of the governing coalition in their manifestations. In the understanding of the Deputy Mayor, of the majority of Councilors favorable to the Project and of the companies of mobile telephony, the problematic must be analyzed, exclusively, from its perspective of technology and science, without ideologization. On the other hand, scientific knowledge contrary to its interests is ignored, being simply labeled as ideological. The former Councilor (1996-2004), E10, author of Law no $8.896 / 2002$, refutes this supposed separation between the scientific and the ideological:

(...) in the city there was already another logic, the logic that came from the World Cup, and that to come to the World Cup, we could not create problems for communications. It's a process that was basically between the City Council and the operators. It had no participation, very little. (...)There is no way to make a breakup (...) the Municipal Public Power, at that time, in the late 1990s, sponsored several seminars, so the technical question was examined. Today those who dictated the technical question were the operators. $(E 10,2016)$

With regard to the debate promoted by the Public Power and social participation, it is clear in the explanation of E10 the difference between the two political moments of Municipal Law $n=8.896$ / 2002. In the first political moment of the creation of legislation in Porto Alegre, it can be seen that the formulation of public policy was in line with the assumptions of social 
participation of Sustainable Development. The same cannot be said in the conduct of the second political moment, which modified Law no 8.896/2002. In this case, former Councilor E10 reflects on the current political context and remembers the difficulties faced in creating the Law, in which the community was the protagonist:

(...) representative democracy today is experiencing a very great crisis (...). What I verify is this: capital quickly places itself in decision-making positions, and society already (...) has great difficulty in putting its positions. And not reaching their positions, cannot put their ideas. In this sense, (...) in the struggle between the interests of the community and capital, always wins the interests of capital. And we live a phase (...) that more than ever the liberal model goes deeper. (...)At that time, I can say that the interest of the population was a stronger vector than the interest that some Councilors defended. All i'm saying is that the community was so strong, (...) that it was able to overcome unhealthy commitments of representative democracy. (E10, 2016)

This interpretation of E10 on the crisis in representative democracy and the advancement of the liberal model must be emphasized, since Sustainable Development is increasingly being discussed as an imperative need for municipalities, and their failure may result in environmental degradation and future generations. In this context, the discussion on Sustainable Development in cities cannot forget the political dimension and democratic governance, as Satterthwaite (2004), Allen (2009) and Sachs (2004) emphasize. For Menegat and Almeida (2004), the participation of citizens, as well as essential for Urban Environmental Management, is a condition for the construction of a city vision supported by the urban-social-environmental system:

This construction does not take place only in the conceptual terrain. Although a deep understanding of local reality is needed, full city vision is only effective in terms of a local social process. That is, it's constituted when there is the common effort of every citizen, social group, institution, and, of course, local government. Otherwise, the city view is partial and, in this case, serves as a tool to deepen urban segregation and environmental problems, rather than to solve them. (...)That is, the city as a system requires the participation of citizens, under penalty of becoming unknown or dysfunctional. (...).In this way, the individual can be understood as an administrator of his own environment, rather than a citizen who must merely follow the normative precepts of the society in which he lives. In this way, citizens are empowered to formulate public policies and socially control the state. (Menegat \& Almeida, 2005, p. 185)

In this direction, a reflection on Sustainable Development, and its relationship with the participation of society in the decision-making process of the cities, should be considered here. Pointed by Veronese (2013), the debate about the risks of RBSs in the country is captured by state agents and public entities, without the protagonism of associations dedicated to the subject. In the case of Porto Alegre, various social actors, such as representatives of Universities, Neighborhood Associations, Public Ministry, Executive and Legislative Powers, actively participated in the process of formulating public policies of RBSs at the local level, in especially in the first political moment analyzed. In this way, organized citizenship is able to socially control the state. In the opposite direction, in the second political moment, the strategy of judicialization of public policy by companies and the primacy of the Executive in the elaboration of the Project Law meeting, above all, the demands of the operators, and provoke a retreat of social actions, in disagreement with the assumptions of Sustainable Development in cities and Urban Environmental Management. 


\section{CONCLUSION}

The changes in the legislation of Porto Alegre have reignited the debate about the implantation of RBSs by the cellular operators in the city. With regard to social participation in the public policies of RBSs in the Capital, two political moments were explored. The first, in the genesis of Municipal Law no 8.896/2002, involved a joint effort of social actors, which aroused more precautionary actions of the Municipal Public Power for the thematic, in relation to the regulation established in the federal scope. After the approval of the Municipal Law, the research testified the positioning of companies facing this municipal public policy in the courts, alleging their unconstitutionality, and not adapting to the rules established at the local level.

The second started with a proposal for updating the Law by companies, represented by FIERGS technicians, in the City Council in 2011, which resulted in Legislative Law Project no 160/2011. Considered very soft in relation to companies, Law Executive Project 57/2013 was proposed, which was approved in 2014, with only a Public Hearing, thanks to a judicial decision filed by AGAPAN. As examined in the research, specialists and technicians in the telecommunications area ensured that protective levels are met by mobile operators without any prejudice to their activities. However, in the discussion of Executive Law Project no 57/2013, an opportunity was lost to improve the legislation of Porto Alegre regarding its health aspects and emission levels of non-ionizing electromagnetic radiation in the city, constituting a setback for environmental policy, since it is possible to harmonize more restrictive norms without impeding the operation of the mobile telephone system.

In the debate about the installation of RBSs in the urban environment, involving the community, organizations and the Public Power, the political dimension of Sustainable Development of cities was emphasized and the citizen participation sphere in Urban Environmental Management, proposed by Menegat and Almeida (2004). Through a really democratic governance, one of the prerogatives for compliance with Agenda 21, the Public Authorities must intermediate the possible tensions between the communities and the cellular operators, guaranteeing safety standards of radiofrequency electromagnetic field, as well as services of telecommunication excellence for its users. Therefore, promoting Sustainable Development in the urban environment, without strengthening representative democracy at the local level, is nothing more than a fallacious discourse of sustainability in cities.

As verified in the analysis of the RBSs legislation in Porto Alegre, especially in the first political moment, it is necessary to encourage political decentralization, as this process favors citizen participation in decision-making and formulation of environmental public policies at the local level, contributing to the consolidation of Sustainable Development in cities and for Urban Environmental Management.

Regarding the research limitation, although the telecommunications companies and their union were contacted, there was no positive return for the participation of the interview stage. It should be highlighted the importance of using observation and legislative-documentary sources to determine the positioning of companies around the public policy decision-making process of implementing RBSs. In the context of the precautionary principle, the emergence of new technologies such as 5G, and its use by companies, and the uncertainty in scientific and political debates, it is suggested to continue the research for a broad understanding of the study phenomenon, using the category of controversies to analyze how the different actors discuss the case of the emergence of $5 \mathrm{G}$ in Brazil. 


\section{REFERENCES}

Agência Nacional de Telecomunicações - Anatel. (2001). Telefones Celulares em Operação Somam 25,4 Milhões. Disponível em: <www.anatel.gov.br/Portal/verificaDocumentos/documento. asp ? numeroPublicacao $=26947$ \&assuntoPublicacao $=$ Telefones $\% 20$ celulares $\% 20 \mathrm{em} \% 20$ opera\%E7\%E30\%20no\%20Brasil\%20em\%20maio\%20somam\%2025,4\%20milh\%F5es\&caminhoRel=null\&filtro=1\&documentoPath=biblioteca/releases/2001/release_26_06_2001(2).pdf $>$. Acesso em: 15 dez. 2017.

Agência Nacional de Telecomunicações - Anatel. (2002). Resolução $n^{\circ}$ 303. Disponível em: http://www.iap.pr.gov.br/arquivos/File/Legislacao_ambiental/Legislacao_federal/RESOLUCAO_ ANATEL_303_2002.pdf. Acesso em: 15 dez. 2017.

Agência Nacional de Telecomunicações - Anatel. (2015a). Em outubro, Brasil soma País 276,79 milhões de acessos móveis. Disponível em: <http://www.anatel.gov.br/institucional/index.php/ noticias/noticia-dados-01/840-em-outubro-brasil-soma-273-79-milhoes-de-acessos-moveisboas-vindas>. Acesso em: 15 de dez. 2017.

Agência Nacional de Telecomunicações - Anatel. (2015b). Relatório das Estações por Localidade. Disponível em: <sistemas.anatel.gov.br/stel/consultas/ListaEstacoesLocalidade/tela. asp?pNumServico=010> Acesso em: 15 dez. 2017.

Allen, Adriana. (2009). Sustainable cities or sustainable urbanisation. UCL's journal of sustainable cities. Summer edition of "palette".

Antunes, Paulo de Bessa. (2013). Direito ambiental. 15. ed. - São Paulo: Atlas.

Beck, Ulrich. Sociedade de risco: rumo a uma outra modernidade. São Paulo: Editora 34.

Bioinitiative Report. (2012). Bioinitiative 2012: A Rationale for Biologically-based Exposure Standards for Low-Intensity Electromagnetic Radiation. Disponível em: <http://www.bioinitiative. org>. Acesso em: 15 dez. 2017.

Brasil. (1981). Lei n.o 6.938. Disponível em: <http://www.planalto.gov.br/ccivil_03/Leis/L6938. htm>. Acesso em: 15 dez. 2017.

Brasil. (1988). Constituição da República Federativa do Brasil. 1988. Disponível em: <http://www. planalto.gov.br/ccivil_03/Constituicao/Constituicao.htm> Acesso em: 15 dez. 2017.

Brasil. (1995). Agenda 21. Brasília: Câmara dos Deputados, Coordenação de Publicações. Disponível em: <http://www.onu.org.br/rio20/img/2012/01/agenda21.pdf>. Acesso em: 15 dez. 2017.

Brasil. (2001). Lei n.o 10.257. Disponível em: <www.planalto.gov.br/ccivil_03/leis/leis_2001/ I10257.htm>Acesso em: 15 dez. 2017.

Cooper, Donald R.; Schindler, Pamela S. (2011). Métodos de pesquisa em administração. 10 ed. Porto Alegre : Bookman, 2011.

Diniz, Eliezer Martins. (2002). Os resultados da Rio+10. Revista do Departamento de Geografia, 15, (31-35). 
Dode, Adilza. (2010). Mortalidade por Neoplasias e a Telefonia Celular no Município de Belo Horizonte Minas Gerais. Tese de doutorado, Programa de Pós-Graduação em Saneamento, Meio Ambiente e Recursos Hídricos, Universidade Federal de Minas Gerais. Minas Gerais, 266p.

Eger, H., Hagen, K. U., Lucas, B., Vogel, P., \& Voit, H. (2004). Einfluss der räumlichen Nähe von Mobilfunksendeanlagen auf die Krebsinzidenz. Umwelt-Medizin-Gesellschaft 17, 4.

Flick, Uwe. (2009). Introdução à pesquisa qualitativa. 3o ed. Porto Alegre: Artmed.

Guimarães, Roberto Pereira, \& Fontoura, Yuna Souza dos Reis da. (2012). Rio+20 ou Rio-20? Crônica de um Fracasso Anunciado. Ambiente \& Sociedade, São Paulo, v. 15, n. 3, p. 19 -39, set./ dez.

International Agency for Research on Cancer - larc. (2011). IARC classifies radiofrequency electromagnetic fields as possibly carcinogenic to humans. Disponível em: http://www.iarc.fr/ en/media-centre/pr/2011/pdfs/pr208_E.pdf. Acesso em: 15 dez. 2017.

Menegat, Rualdo, \& Almeida, Gerson. (2004). Sustentabilidade, democracia e gestão ambiental urbana. In: MENEGAT, Rualdo, \& ALMEIDA, Gerson. Desenvolvimento sustentável e gestão ambiental nas cidades: estratégias a partir de Porto Alegre. Porto Alegre: Editora da UFRGS.

Milaré, Édis. (2013). Direito do ambiente. $8^{\circ}$ ed. rev., atual., e ampl. - São Paulo: Editora Revista dos Tribunais.

Parliamentary Assembly. (2011). Resolution 1815. Disponível em: <http://semantic-pace.net/ tools/pdf.aspx?doc=aHR0cDovL2Fzc2VtYmx5LmNvZS5pbnQvbncveG1sL1hSZWYvWDJILURXLW V4dHluYXNwP2ZpbGVpZD0xNzk5NCZsYW5nPUVO\&xsI=aHROcDovL3NIbWFudGljcGFjZS5uZXQ vWHNsdC9QZGYvWFJIZi1XRC1BVC1YTUwyUERGLnhzbA==\&xsItparams=ZmlsZWlkPTE3OTk0> Acesso em: 25 de out. de 2017.

Porto Alegre. (2012). Lei das antenas volta ao debate na Câmara em 2012. Disponível em: <http:// www2.camarapoa.rs.gov.br/default.php?reg=16369\&p_secao=56\&di=2012-01-18>. Acesso em: 15 de dez. de 2017.

Sachs, Ignacy. (2004). Desenvolvimento: includente, sustentável, sustentado. Rio de Janeiro: Geramond.

Satterthwaite, David. (2004). Como as cidades podem contribuir para o desenvolvimento sustentável. In: MENEGAT, Rualdo, \& ALMEIDA, Gerson. Desenvolvimento sustentável e gestão ambiental nas cidades: estratégias a partir de Porto Alegre. Porto Alegre: Editora da UFRGS, 2004.

Seminário Internacional de Radiação Não-Ionizante, Saúde e Ambiente. (2012). Carta do Seminário Estadual sobre os Riscos da Radiação Eletromagnética Não-lonizante para a saúde humana. Disponível em: <http://www.mreengenharia.com.br/artigos_carta.php>. Acesso em: 15 de dez. de 2017.

Schreier, M. (2013). Qualitative content analysis. In: Flick, U. (Ed.). The SAGE handbook of qualitative data analysis. London: Sage, p. 170-183.

United Nations. (1972). Declaração de Estocolmo sobre o Ambiente Humano. Disponível em: <http://portal.iphan.gov.br/uploads/ckfinder/arquivos/Declaracao\%20de\%20Estocolmo\%20 1972.pdf> Acesso em: 15 dez. 2017. 
United Nations. (1987). Our common future. Disponível em: <http://conspect.nl/pdf/Our_ Common_Future-Brundtland_Report_1987.pdf>. Acesso em: 15 dez. 2015.

United Nations. (1992). Declaração do Rio de Janeiro sobre Meio Ambiente e Desenvolvimento. Disponível em: <http://www.onu.org.br/rio20/img/2012/01/rio92.pdf>. Acesso em: 15 dez. 2015.

United Nations. (2013). World economic and social survey 2013: sustainable development challenges. Disponível em: <http://www.un.org/en/development/desa/policy/wess/wess current/wess2013/WESS2013.pdf>. Acesso em: 15 dez. 2015.

United Nations. (2015). Transformando nosso mundo: a Agenda 2030 para o desenvolvimento sustentável. Disponível em: < http://www.pnud.org.br/Docs/TransformandoNossoMundo.pdf>. Acesso em: 15 dez. 2015.

United Nations. (2016). Nova Agenda Urbana. Disponível em: < http://habitat3.org/wp-content/ uploads/NUA-Portuguese.pdf>. Acesso em: 15 dez. 2017.

Veronese, Alexandre. (2013). Antenas de telefonia celular no Brasil contemporâneo: uma avaliação das disputas judiciais entre entidades estatais. Revista de Direito, Estado e Telecomunicações, v. 5 , n. 1 , p. 29-64.

Wolf, R, \& Wolf, D. (2004). Increased Incidence of Cancer near a Cell-Phone Transmitter Station. International Journal of Cancer Prevention, vol. 1, no. 2, abr.

World Bank. (2013). Planning, Connecting, and Financing Cities Now: Priorities for City Leaders. Disponível em: <http://siteresources.worldbank.org/EXTSDNET/Resources/UrbanizationPlanning-Connecting-Financing-2013.pdf>. Acesso em: 15 dez. 2015.

Yin, Robert K. (2015). Estudo de caso: planejamento e métodos. 5o ed. Porto Alegre: Bookman, 2015.

Zero Hora. (2005a). Prefeitura pretende remover 154 antenas de telefonia. Edição 30 de abr. de 2005. Porto Alegre: Grupo RBS.

Zero Hora. (2005b). Impasse ameaça 1 milhão de usuários de celular. Edição 8 de mai. de 2005. Porto Alegre: Grupo RBS.

Zero Hora. (2006). Artigos. Edição 22 de mai. de 2006. Porto Alegre: Grupo RBS.

Zero Hora. (2013). Sinal polêmico: nova Lei das antenas empaca. Edição 4 de mai. de 2013. Porto Alegre: Grupo RBS. 


\begin{tabular}{|c|c|c|}
\hline Contribution & [Author 1] & [Author 2] \\
\hline 1. Definition of research problem & V & \\
\hline 2. Development of hypotheses or research questions (empirical studies) & V & \\
\hline 3. Development of theoretical propositions \\
(theoretical work) & & \\
\hline 4. Theoretical foundation / Literature review & & \\
\hline 5. Definition of methodological procedures & $\mathrm{V}$ & $\mathrm{V}$ \\
\hline 6. Data collection & & \\
\hline 7. Statistical analysis & $\mathrm{V}$ & $\mathrm{V}$ \\
\hline 8. Analysis and interpretation of data & & \\
\hline 9. Critical revision of the manuscript & & \\
\hline 10. Manuscript writing & $\mathrm{V}$ \\
\hline 11. Other (please specify) &
\end{tabular}

